Jurnal Teknologi, 42(A) Jun. 2005: 75-90

(C) Universiti Teknologi Malaysia

\title{
DESIGN OF MULTI-FAMILY PRODUCT PLATFORM BY USING MODULARITY APPROACH
}

\author{
A. B. ABDULLAH ${ }^{1 *}$, A. R. KAMARUDDIN ${ }^{2}$ \& Z. M. RIPIN ${ }^{3}$
}

\begin{abstract}
Design for modularity is one of the best design technique as it promotes better and faster designing process. Due to functional independence and physical similarities, it tends to drive for better platform development. This paper discusses the application of modularity approach to design platform from multi-family product. By utilizing the conventional heuristics rules to identify modules, a platform is then developed so that it can be shared among products. Three consumer products from different family were used as case study. As a result, new designs were proposed that depicted several improvements to the products.
\end{abstract}

Keywords: Modular product design, heuristic approach, design platform

\begin{abstract}
Abstrak. Reka bentuk untuk pemodularan adalah antara teknik reka bentuk yang terbaik yang mana ia menjanjikan proses reka bentuk yang lebih baik dan lebih cepat. Berdasarkan ciri kebebasan fungsi dan kesamaan fizikal yang dimilikinya, ia akan menjurus kepada penghasilan platform yang lebih baik. Kertas kerja ini membincangkan aplikasi pendekatan pemodularan untuk menghasilkan platform reka bentuk daripada produk pelbagai keluarga. Garis panduan heuristik sedia ada digunakan untuk mengenal pasti modul, dan kemudiannya platform akan dihasilkan dan boleh dikongsi oleh kesemua produk berkenaan. Tiga produk pengguna daripada keluarga yang berlainan digunakan sebagai kajian kes. Keputusan menunjukkan reka bentuk baru telah dapat dihasilkan yang memaparkan beberapa penambahbaikan.
\end{abstract}

Kata kunci: Reka bentuk produk modular, pendekatan heuristik, platform reka bentuk

\subsection{INTRODUCTION}

Modular and integral architectures are techniques used by designers to design a product. For most designers, modular architecture is the best technique as it promotes better and faster designing process. Furthermore, product design using this technique requires less effort to redesign [1]. It can also reduce the number of parts and components compared with products designed using integral architecture. Pahl and Beitz [2] defined modular products as machine assemblies or components that accomplish an overall function through combination of distinct building block or

${ }^{1,2 \& 3}$ School of Mechanical Engineering, Universiti Sains Malaysia, Engineering Campus, 14300. Nibong Tebal, SPS, Penang.

*Corresponding author: Email: mebaha@eng.usm.my 
modules. Modules can be described as physical structures that have a one to one correspondence with functional structures [3]. These characteristics i.e. similarity and interaction between components can be promoted for platform development. A product platform can be best understood as a part of product that can be shared among its variants to perform different functions [4]. Modular architecture is capable of increasing product simplification. Modular architecture does not mean that the number of parts are always reduce because; sometimes the addition of some parts can improve overall product performance. For example, a product without components such as screws and nuts may not require many tools in assembly. Special feature of modular products attract customers as they are easy to use and sometimes can be upgraded [5]. A very good example of a modular product is a personal computer. Many success in product platform has been published and marketed [6].

There are many techniques used to design modular product which focus more in identification of modules [7]. In the area of product platform, many techniques are also used. Methods such as Generational Variety Index (GVI) and Coupling Index (CI) are widely used in product platform to increase product variety [8]. These methods are used for complex product such as electronic product that rapidly evolved with time. Sudjianto et al. [9] has proved that modularity can enhanced the process of platform development from multi-brand product, while Abdullah and Ripin [10] used modularity index to identify platform that can be shared among the products from similar brand and family. However, very few research has been conducted in identifying platform for multi-family product. Here multi-family product can be described as products which are different in terms of function and physical appearance. This paper intends to prove that modular architecture can be used to support the design of platform from multi-family product which generally have different product configurations. The method of module heuristic developed by Stone $e t$ al. [11] will be utilised to identify modules and after that product platform design is suggested.

\subsection{FUNCTION STRUCTURE}

Before using the method of module heuristic, a fine function structure must first be built. Function structure consists of flow of material, energy and signal involved while using a product [12]. To build a function structure, a standard vocabulary of functional basis must be used and several steps must be followed. A black box model is used as a representation model of the product's overall function and input/ output flow [11]. The overall function of the product is expressed in verb-object form. An example of the Black Box model for a power screwdriver is shown in Figure 1. 


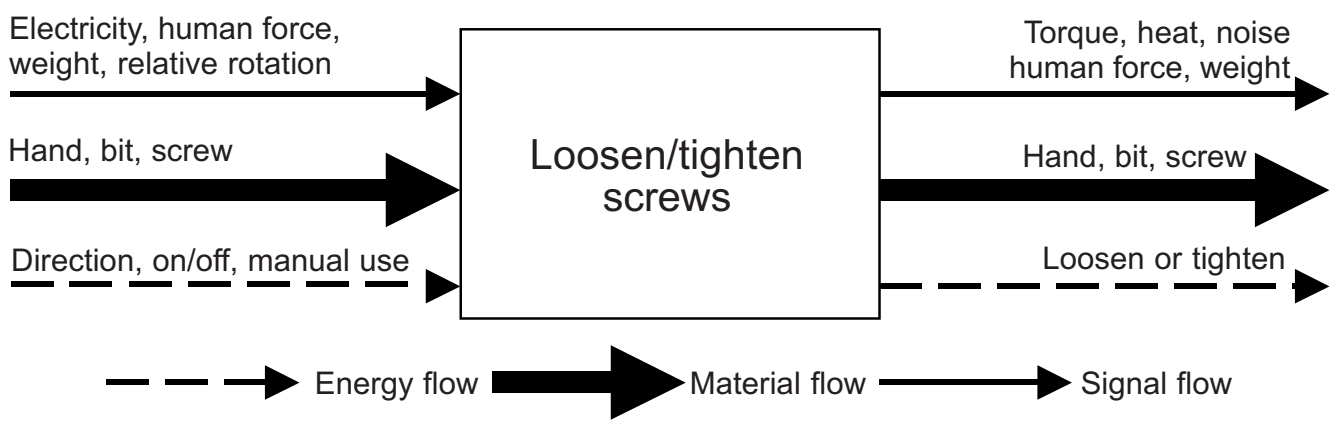

Figure 1 A block box model for a power screwdriver

\subsection{THE MODULE HEURISTICS METHOD}

The method of module heuristics consists of three rules in identifying modules. The necessary starting point is a well refined functional model as derived in the previous section. Then, three heuristics will be applied to the function structure and this will be explained as follows;

\section{a) Dominant flow heuristic}

The dominant flow heuristic examines each non-branching flow of a function structure and group the sub-function that flows through until it exits in the system or it transformed into another flow. The identified sets of sub-functions in defined as a module that deals with the flow traced through the system. The identified sub-function forms the boundary, or interface of the module. Others flow, in addition to the traced flow that crosses the boundary intersections between the module and the remaining product.

A dominant flow module is shown schematically in Figure 2. To implement the module, conduits must be specified to carry the interactions across the interface.

\section{b) Branching flow heuristic}

The second heuristic is referred to as branching flow and requires identification of flows associated with parallel function chains. Each limb of a parallel function chain defines a potential module and is shown schematically in Figure 3. The module is formed by the sub-functions that make up the limb (technically, each limb consists of a sequential function chain). All modules (one per limb) must interface with the product at the flow's branch point. All flows that cross this interface are the interactions between the remaining product and the module [11]. 


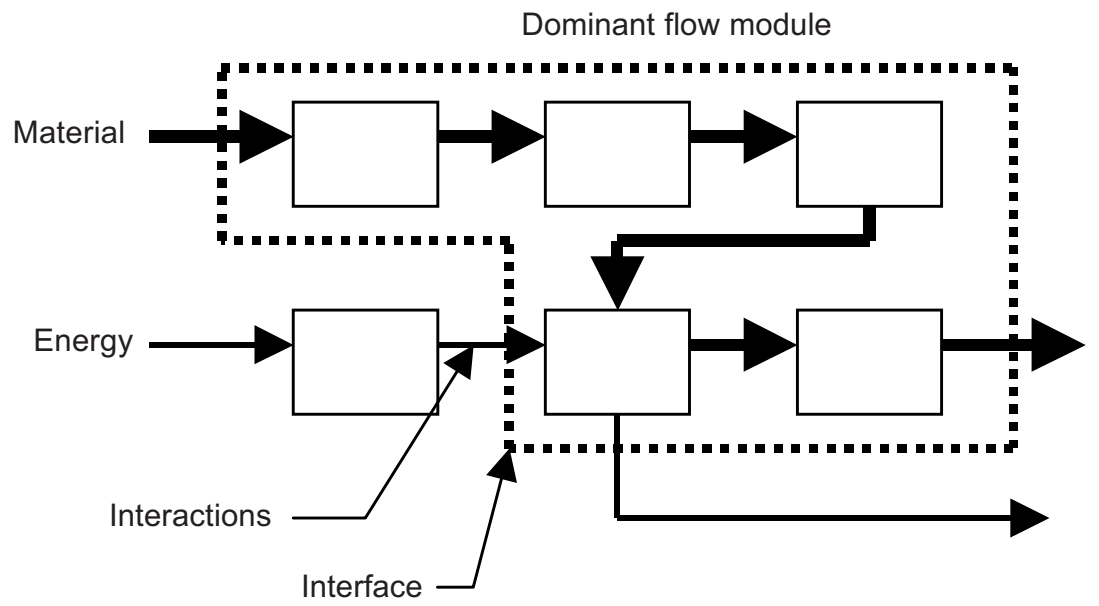

Figure 2 Dominant flow heuristic applied to a generic function structure

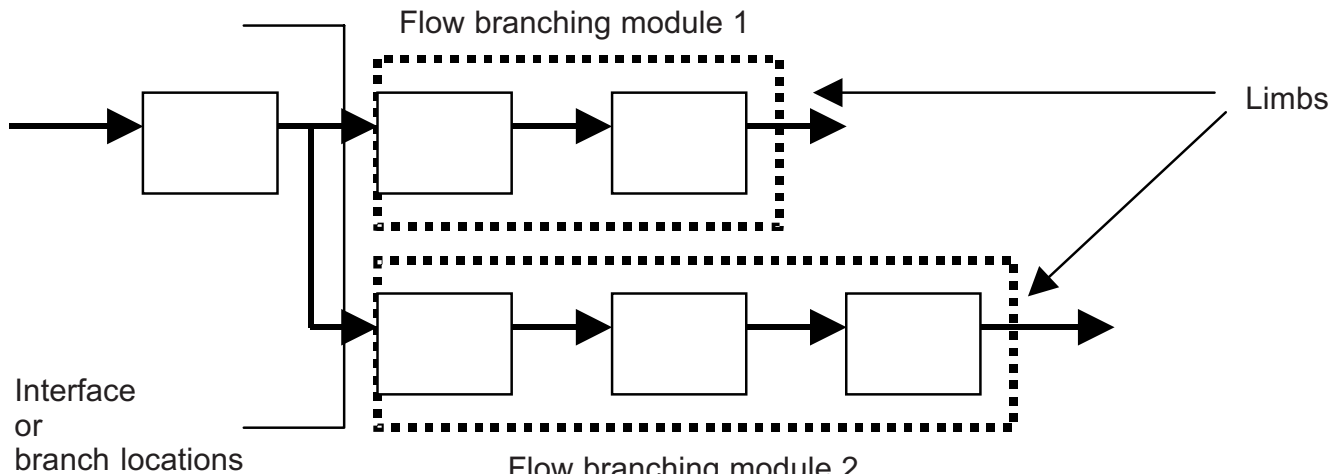

Figure 3 Flow branching heuristic applied to a generic function structure

c) Conversion-transmission heuristic

The third heuristic rule deals with conversion sub-functions and conversion to transmission chains. Conversion sub-function accepts a flow of material or energy and converts the flow to another form of material or energy. In standard verb-object form, a conversion sub-function appears as flow A converted to flow B. In many cases, these conversion sub-functions are already components or modules themselves. For instance, electrical motors, hydraulic cylinders, and electrical heaters can all be represented by a single conversion sub-function and exist in a chain with a transmit sub-function (or transport sub-function for material flow). The chain presents an opportunity to form a module. This converts energy or material to another form and 

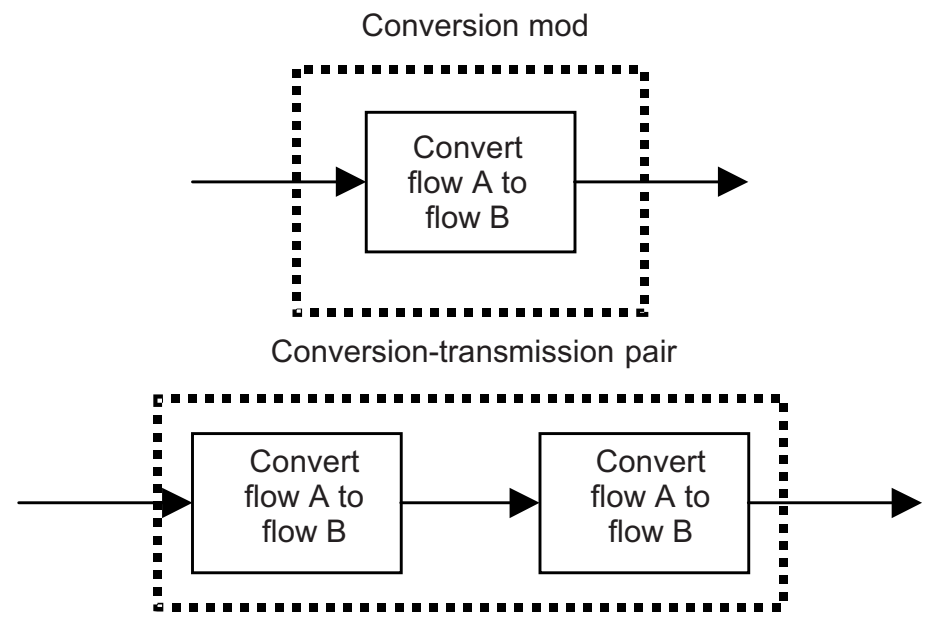

Conversion-transmission chain

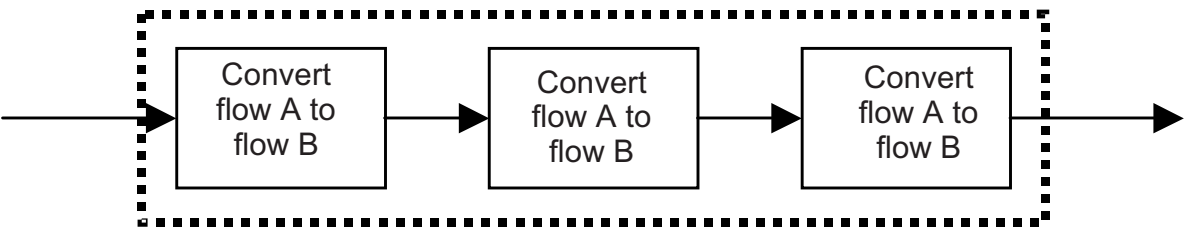

Figure 4 Conversion-transmission applied to a generic set of sub-functions

then implements (transmits or transports) that new form of energy or material. The method of the conversion-transmission heuristic is shown schematically in Figure 4.

\subsection{METHODOLOGY}

An overview of the methodology used to identify the platform and module of product in this study is outlined in the flow chart shown in Figure 5.

Problem of each product must be understood at the first stage. In order to easily understand the product functionality, it should be broken into smaller parts and components. Every parts and components functionality is then presented in the form of a black box model and after that the function structure for each product can be developed. Only after the complete function structures for each of the product have been developed that the method of module heuristics can be applied to identify modules. The modules are then listed to assist in identifying the platform by selecting the similar modules own by the products in the family. The platform is then developed. 


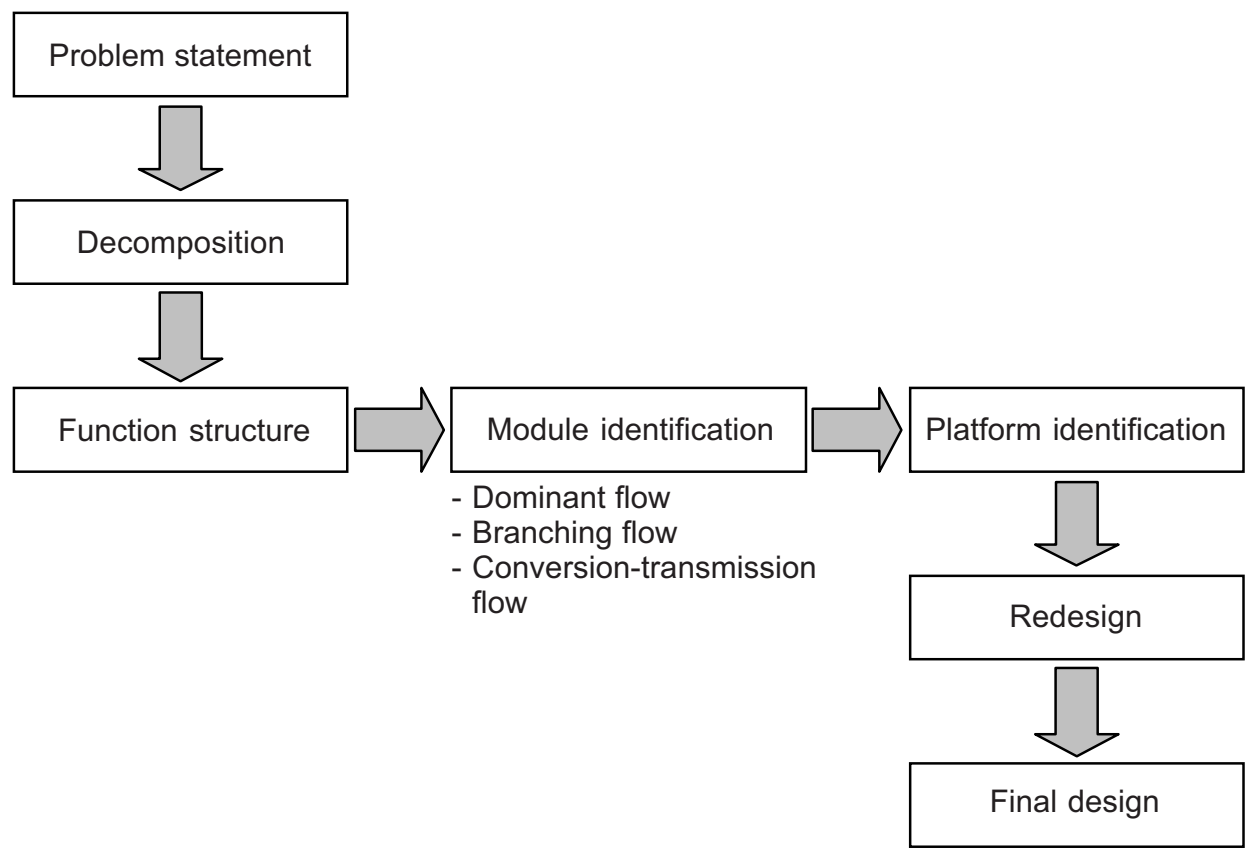

Figure 5 Platform design process methodology

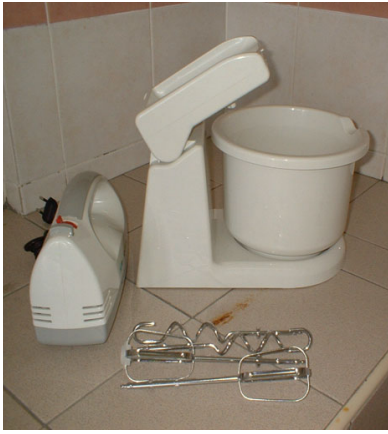

(a)

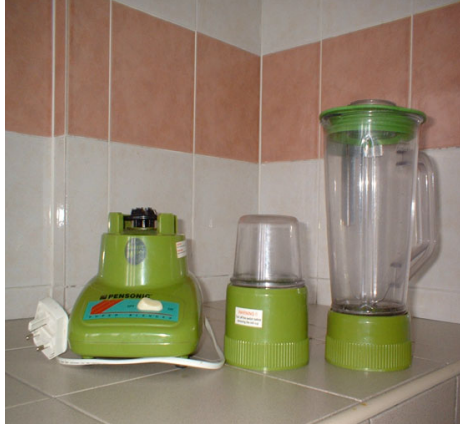

(b)

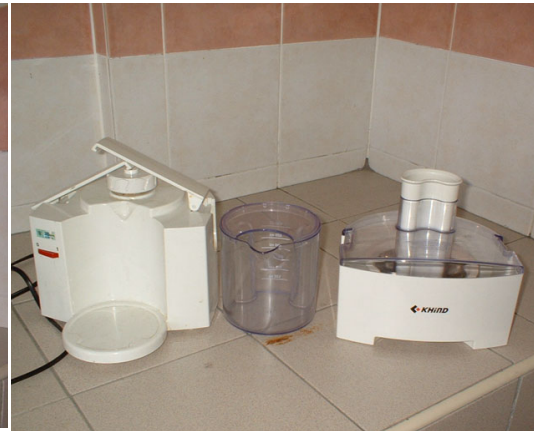

(c)

Figure 6 Three customer products from different families are used as case studies, (a) flour mixer, (b) electric blender and (c) juice extractor

\subsection{IMPLEMENTATION}

In this project, 3 types of consumer products from different families were taken into were consideration. The products were flour mixer, blender and juice extractor, as shown in Figure 6. Generally, all three products have several similarities in terms of functionality but each has obvious differences in physical appearance. Through this section, similarities in terms of functionality of the products will be identified and 
new designs, which also have similarities in physical appearance, will be suggested at the end of the paper.

\subsection{Problem Statement}

In the market, most consumer products have similar operation to accomplish their tasks such as motor to rotate blade for blender and extractor, and beater for mixer but unfortunately, initially they are designed distinctly, different from the others.

\subsection{Function Structure}

In order to build function structure for each product as explained in the previous section, the black box models for each product must be developed. Generally, black box model for mixer, blender, and juice extractor can be demonstrated as shown in Figure 7 (a), (b), and (c).

Next to building a function structure, each flow need to be examined and the function chains built for every one of them. The function chains are then aggregated in order to build the final function structure. The function structure of mixer, blender and extractor are as shown in Figure 8 (a), (b) and (c). To build a systematic and effective function structure, understanding on how the product work and functionality of each component in the product is required.

Modules contain in mixer, blender and juice extractor can only be identified after the function structure is built. In the next section, the results of using the method of module heuristics will be presented.

\subsection{Modules Identification}

All modules are to be identified. However, only modules identified from mixer are discussed here. These are shown in Figure 9 (a), (b) and (c). Modules are depicted by dash lines. Table 1 lists down all the modules identified in the products.

\subsection{Platform Identification}

In order to identify platform, a very basic approach is used that is by observing and identifying similar modules. As a result shown in Table 2, four platforms can be developed:

(i) Transmit electricity module

(ii) Transmit rotation module

(iii) Actuating module, and

(iv) Convert electricity module 


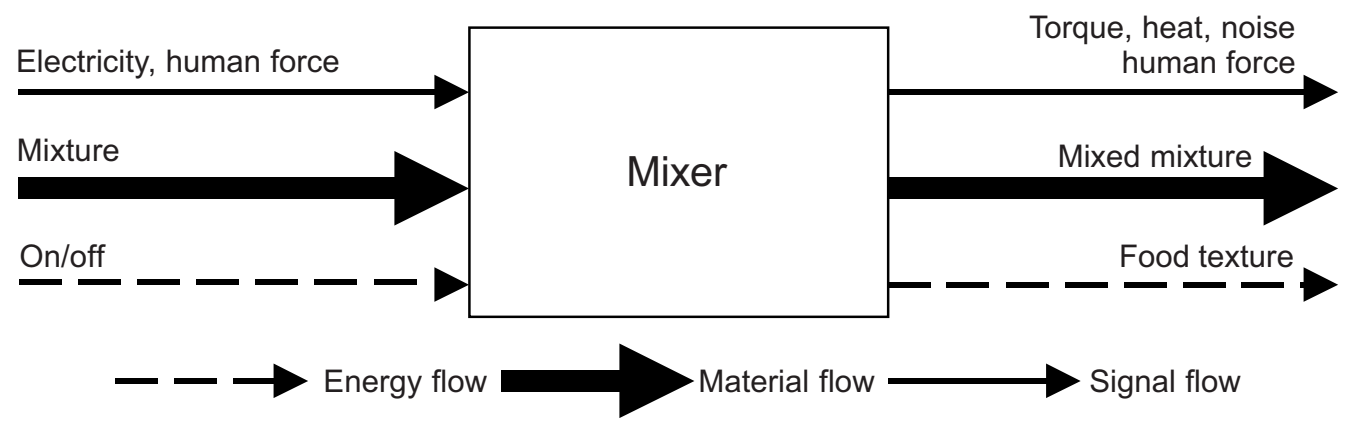

(a)

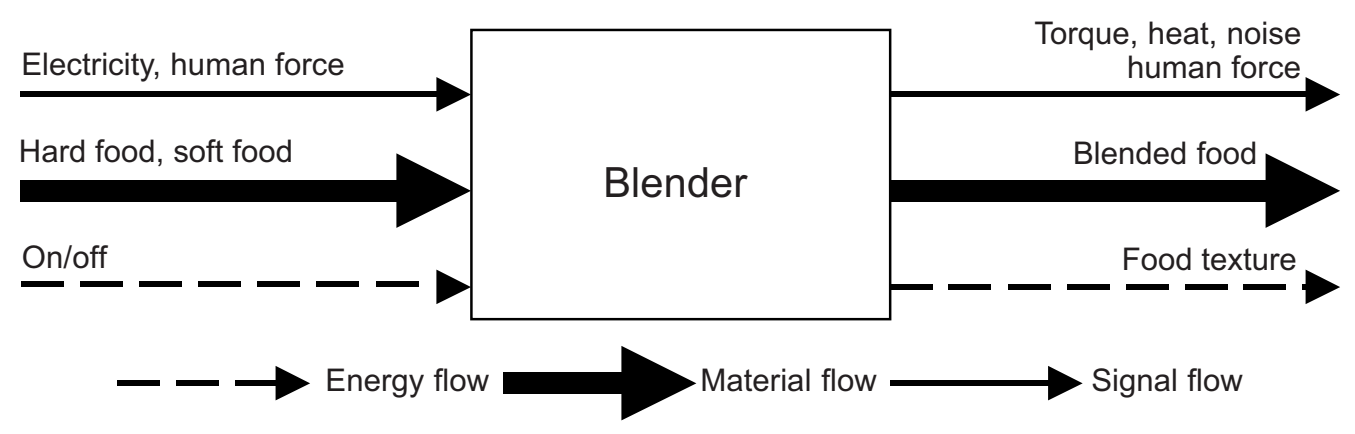

(b)

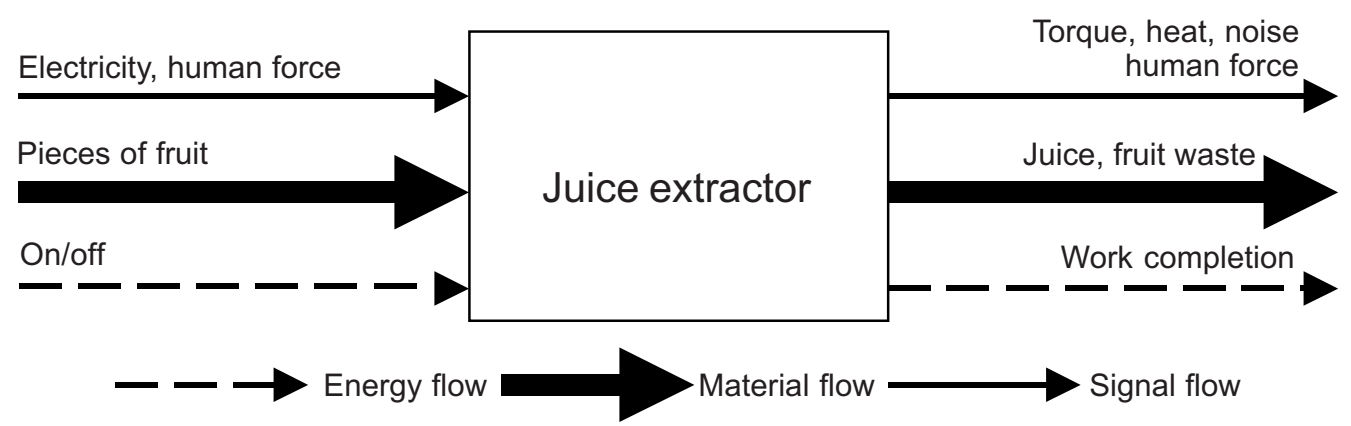

(c)

Figure 7 A black box model of (a) mixer (b) blender, and (c) juice extractor 


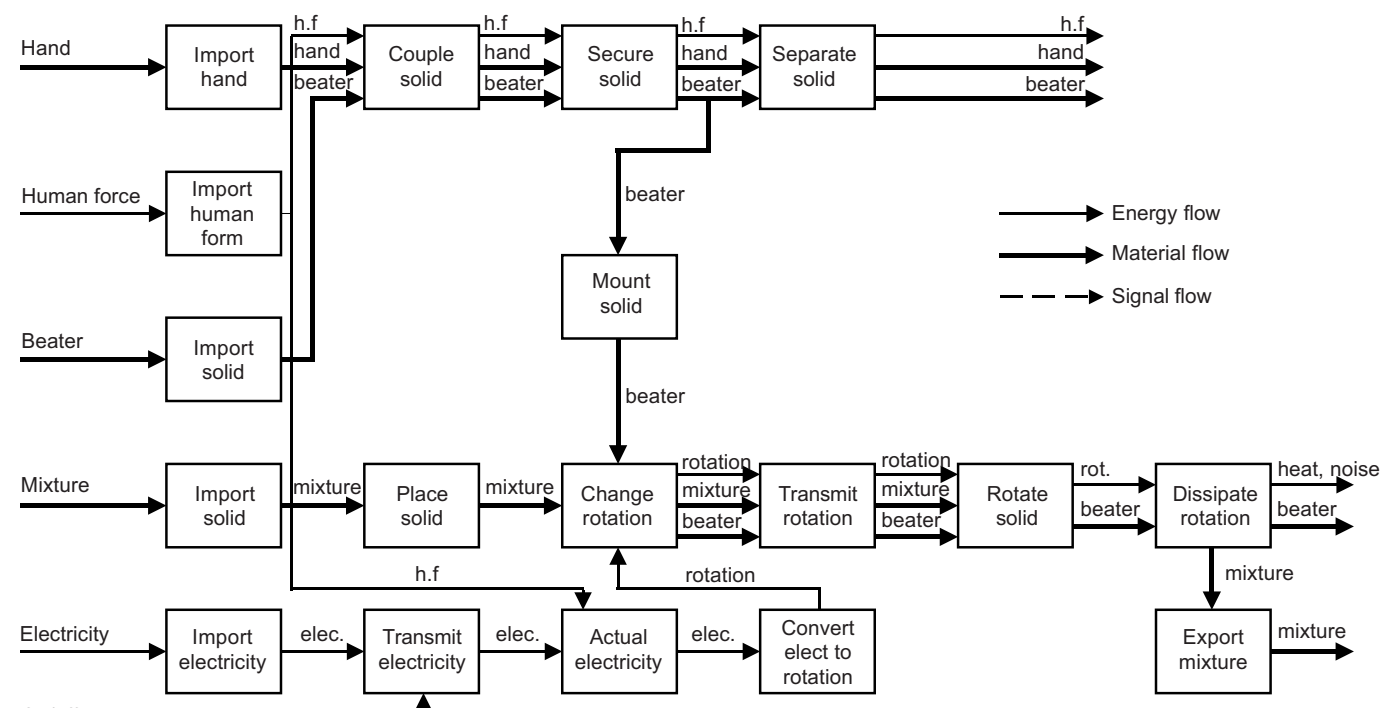
On/off --------$\lrcorner$

Figure 8 (a)

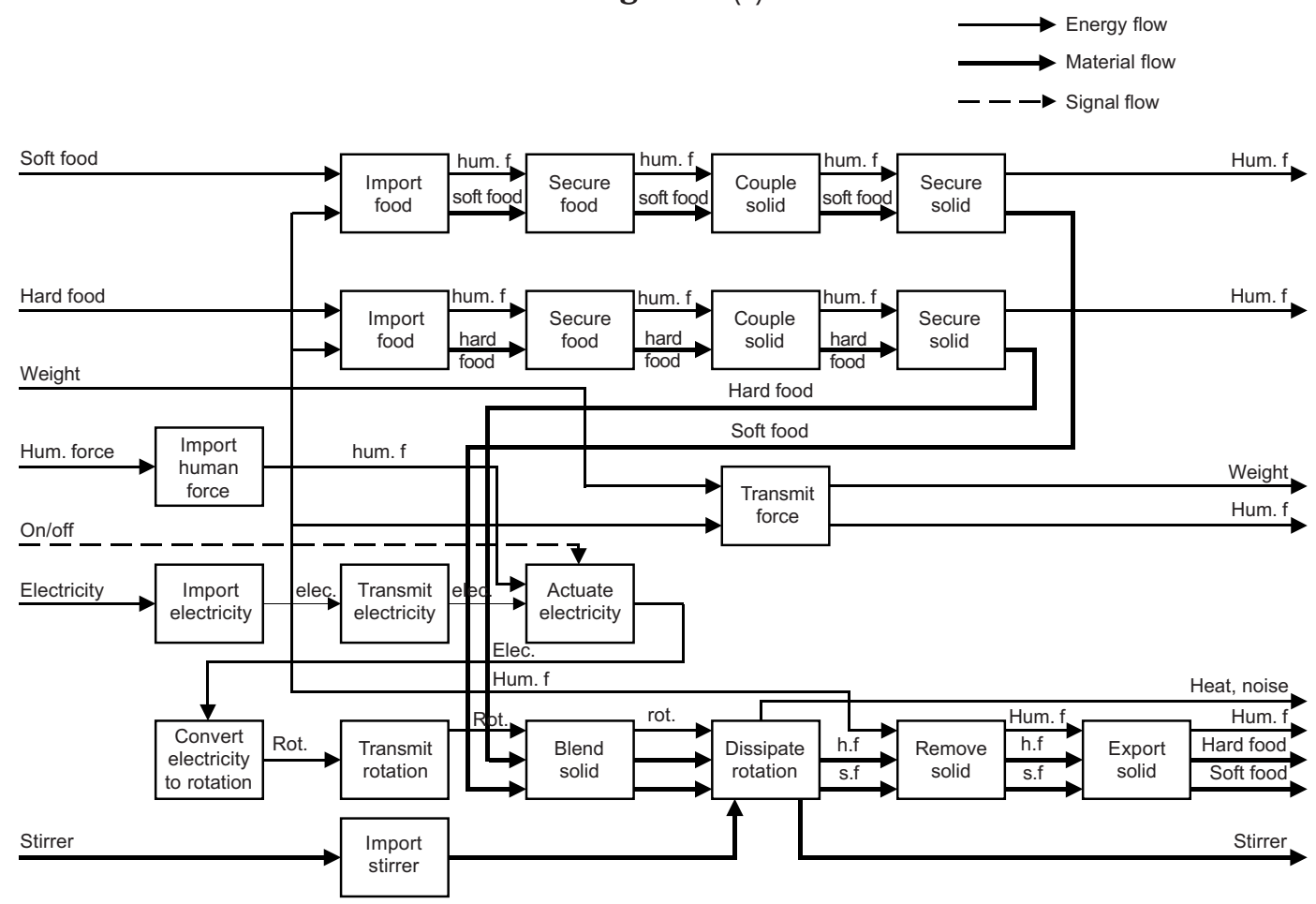

Figure $8(b)$ 


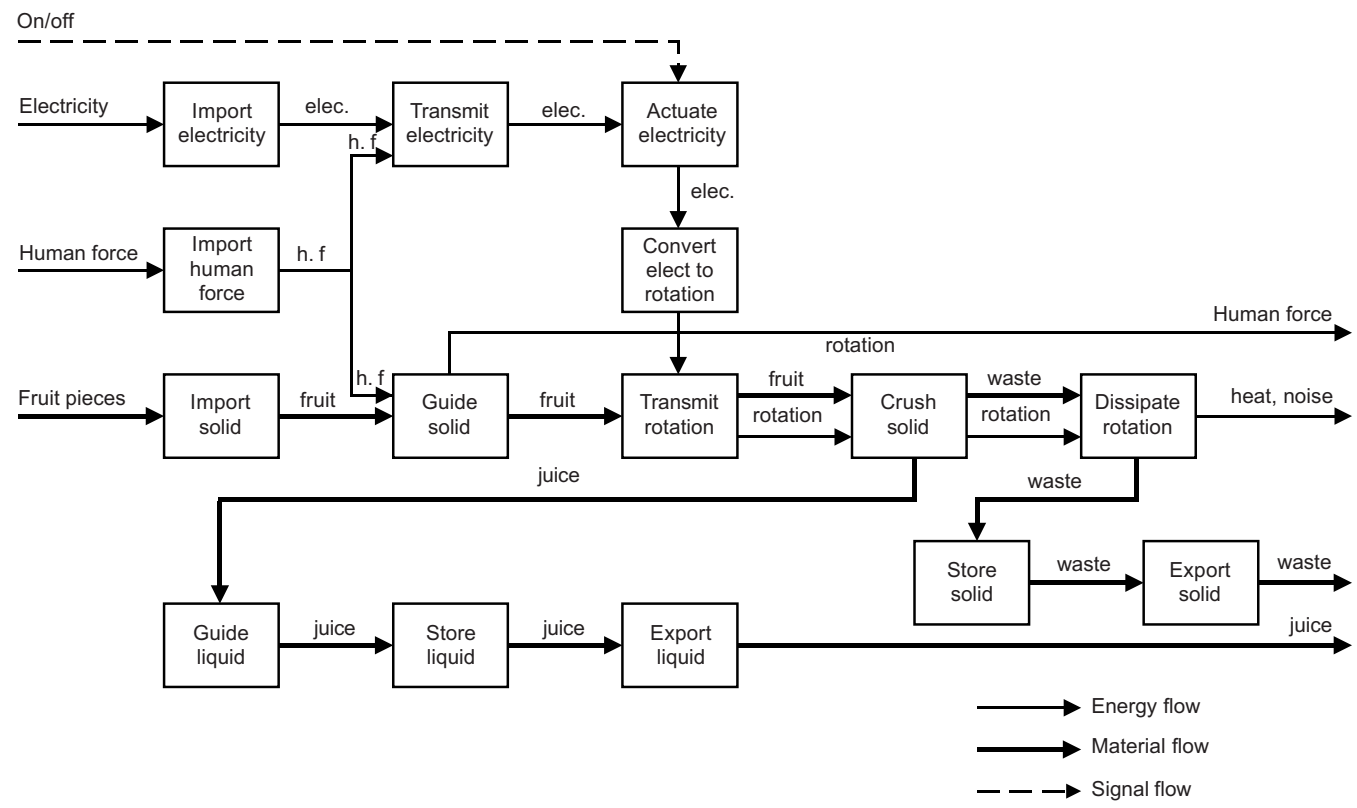

(c)

Figure 8 Function structure of (a) mixer, (b) blender and (c) juice extractor

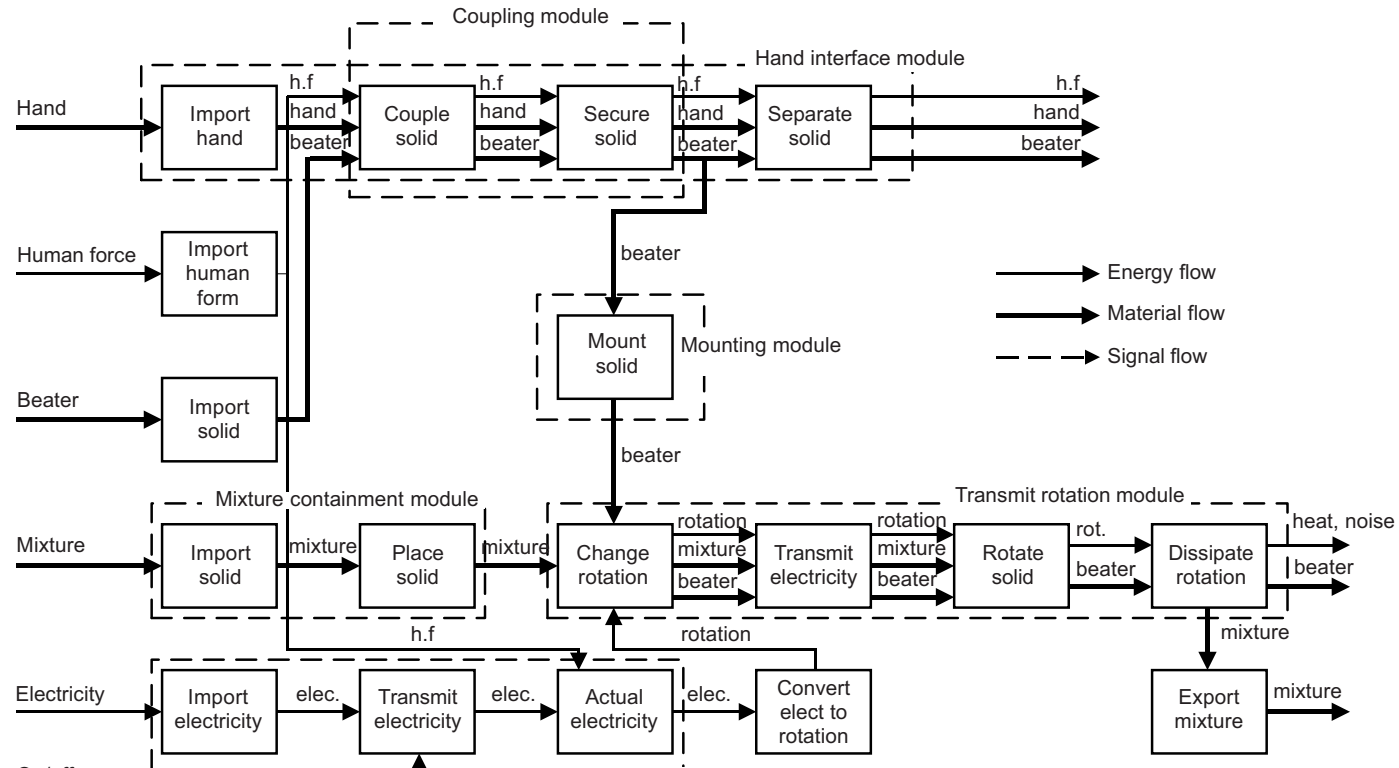

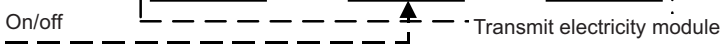

Figure 9 (a) 


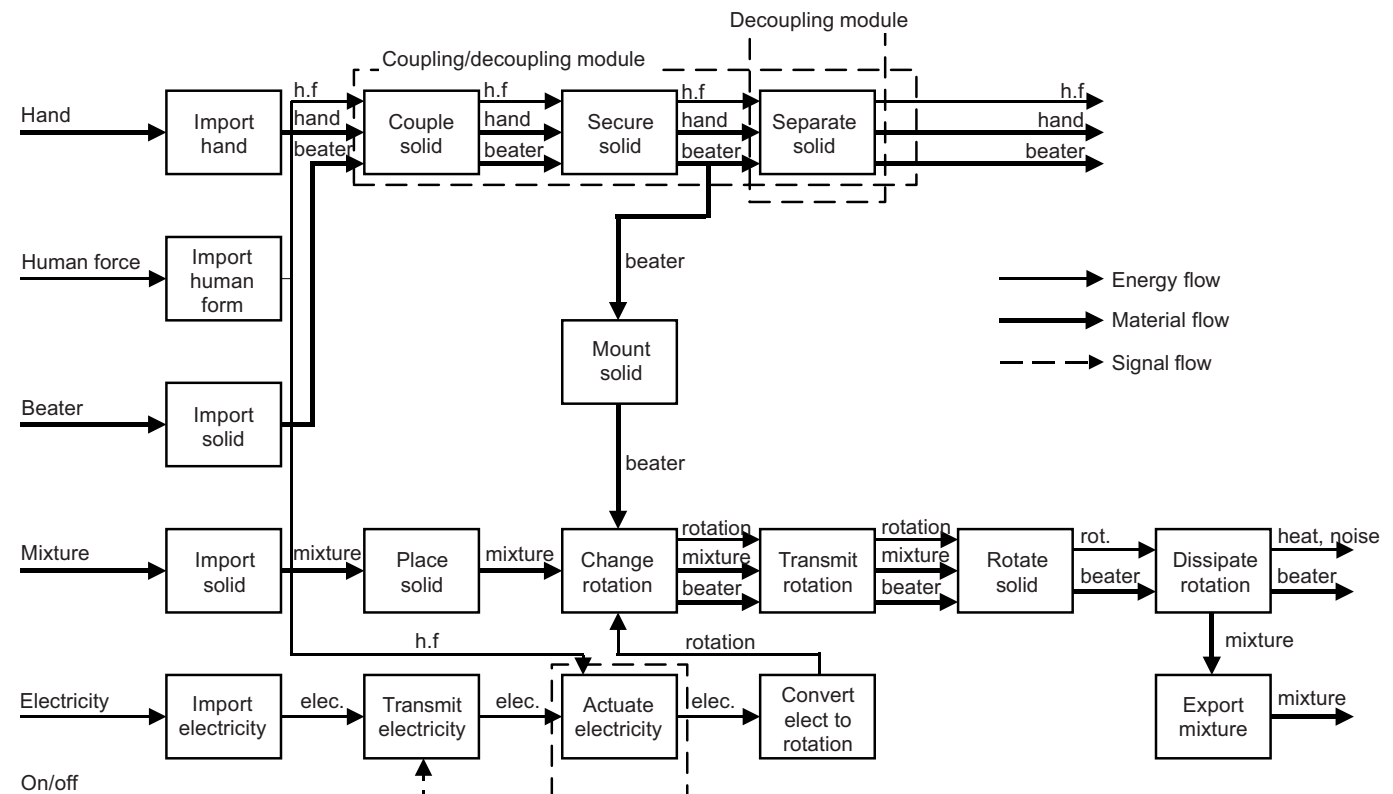

Figure 9 (b)

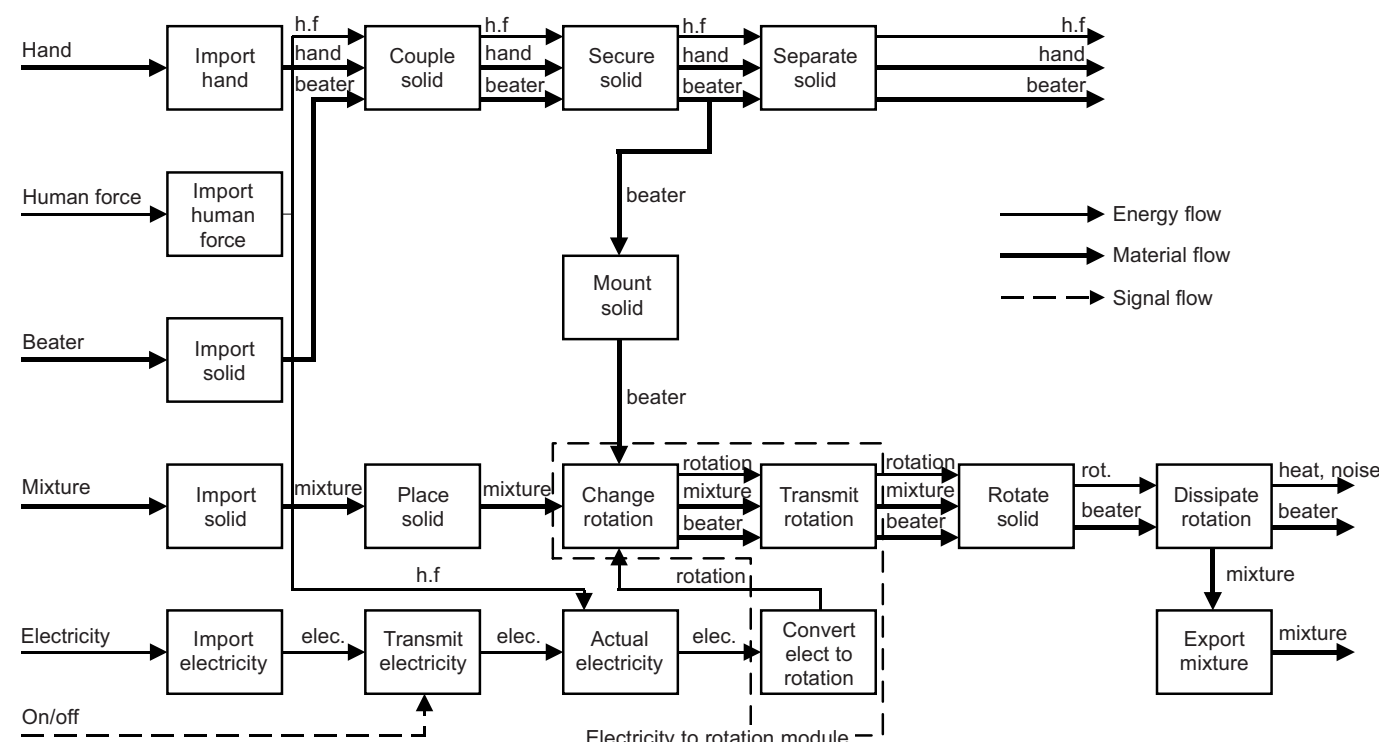

(c)

Figure 9 Modules identified from mixer by using (a) dominant flow, (b) branching flow and (c) conversion-transmission heuristics rules 
Table 1 Module identified in the products

\begin{tabular}{|c|c|c|c|}
\hline & & Module & \\
\hline & Dominant flow & Branching flow & Conversion-trans \\
\hline Mixer & $\begin{array}{l}\text { 1. Hand interface } \\
\text { 2. Coupling } \\
\text { 3. Mounting } \\
\text { 4. Mixture containment } \\
\text { 5. Transmit rotation } \\
\text { 6. Transmit electricity }\end{array}$ & $\begin{array}{l}\text { 1. Coupling/decoupling } \\
\text { 2. Decoupling } \\
\text { 3. Actuating }\end{array}$ & $\begin{array}{l}\text { 1. Convert electricity to } \\
\text { rotation }\end{array}$ \\
\hline Blender & $\begin{array}{l}\text { 1. Soft food containment } \\
\text { 2. Hard food containment } \\
\text { 3. Coupling } \\
\text { 4. Transmit electricity } \\
\text { 5. Transmit rotation }\end{array}$ & $\begin{array}{l}\text { 1. Soft food containment } \\
\text { 2. Hard food containment } \\
\text { 3. Weight transmission } \\
\text { 4. Actuating } \\
\text { 5. Food removing }\end{array}$ & $\begin{array}{l}\text { 1. Convert electricity to } \\
\text { rotation }\end{array}$ \\
\hline Juice extractor & $\begin{array}{l}\text { 1. Transmit electricity } \\
\text { 2. Fruit guide } \\
\text { 3. Transmit rotation } \\
\text { 4. Waste storing } \\
\text { 5. Juice storing }\end{array}$ & $\begin{array}{l}\text { 1. Actuating } \\
\text { 2. Fruit guide }\end{array}$ & $\begin{array}{l}\text { 1. Convert electricity to } \\
\text { rotation }\end{array}$ \\
\hline
\end{tabular}

Table 2 Platform identified from listed modules

\begin{tabular}{|c|c|c|c|}
\hline & & Module & \\
\hline & Dominant flow & Branching flow & Conversion-trans \\
\hline Mixer & $\begin{array}{l}\text { 1. Hand interface } \\
\text { 2. Coupling } \\
\text { 3. Mounting } \\
\text { 4. Mixture containment } \\
\text { 5. Transmit rotation } \\
\text { 6. Transmit electricity }\end{array}$ & $\begin{array}{l}\text { 1. Coupling/decoupling } \\
\text { 2. Decoupling } \\
\text { 3. Actuating }\end{array}$ & $\begin{array}{l}\text { 1. Convert electricity to } \\
\text { rotation }\end{array}$ \\
\hline Blender & $\begin{array}{l}\text { 1. Soft food containment } \\
\text { 2. Hard food containment } \\
\text { 3. Coupling } \\
\text { 4. Transmit electricity } \\
\text { 5. Transmit rotation }\end{array}$ & $\begin{array}{l}\text { 1. Soft food containment } \\
\text { 2. Hard food containment } \\
\text { 3. Weight transmission } \\
\text { 4. Actuating } \\
\text { 5. Food removing }\end{array}$ & $\begin{array}{l}\text { 1. Convert electricity to } \\
\text { rotation }\end{array}$ \\
\hline Juice extractor & $\begin{array}{l}\text { 1. Transmit electricity } \\
\text { 2. Fruit guide } \\
\text { 3. Transmit rotation } \\
\text { 4. Waste storing } \\
\text { 5. Juice storing }\end{array}$ & $\begin{array}{l}\text { 1. Actuating } \\
\text { 2. Fruit guide }\end{array}$ & $\begin{array}{l}\text { 1. Convert electricity to } \\
\text { rotation }\end{array}$ \\
\hline
\end{tabular}


These are represented in Table 2 in shaded blocks. It shows that these products share components and systems that are related to the motor and switch modules.

\subsection{PROPOSAL FOR NEW DESIGN}

After identifying the platform, a conceptual platform is selected. Several potential features can be taken into consideration, for example remote control. Another potential is enhancing the cleaning process of the part from wastage and dirt.

Waste storing/cleaning module may also be developed. A new part can be added to the juice extractor's variant so that the waste can be removed without disassembling the machine. This is because, typically juice extractor consists of blade, main housing and top cover that need to be disassembled before waste can be removed as shown in Figure 10.

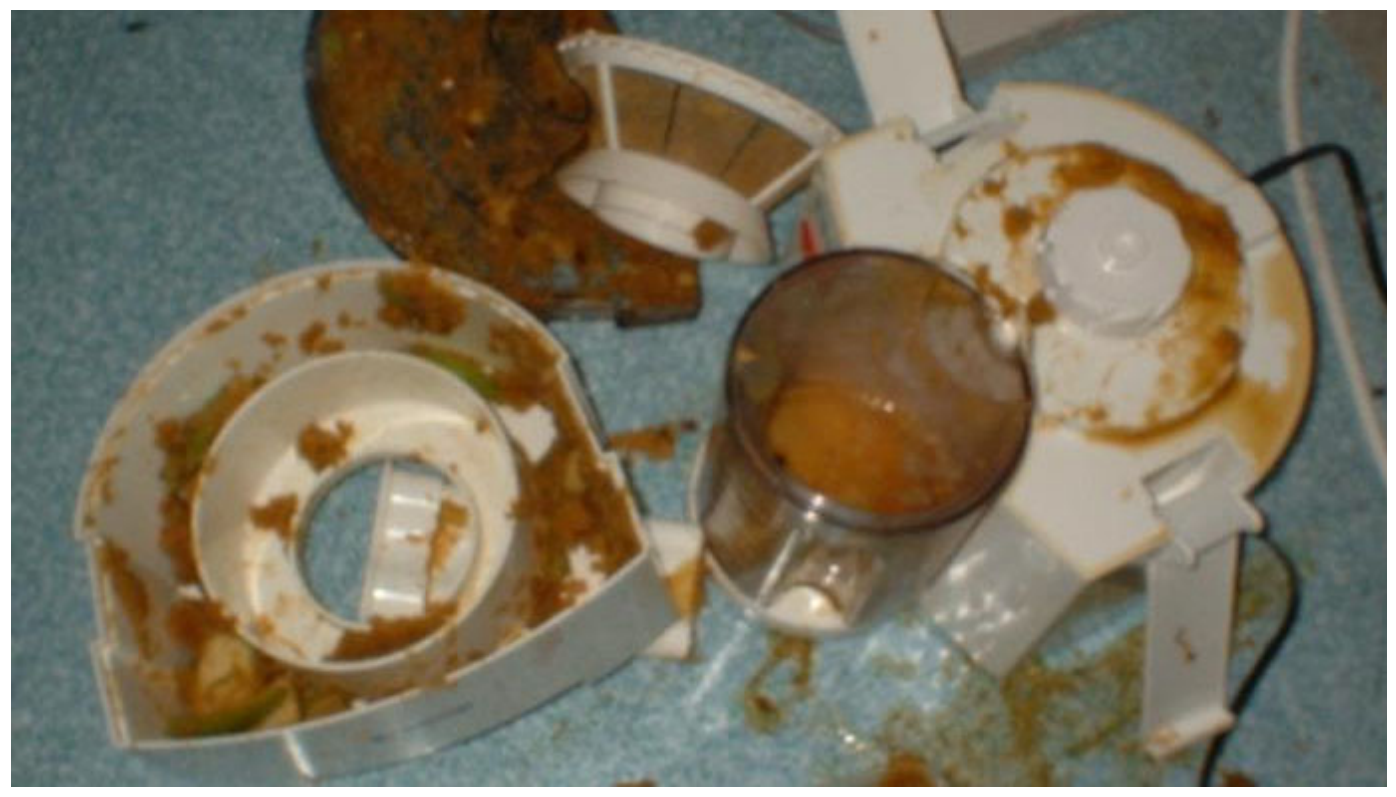

Figure 10 Machine had to be disassembled to remove waste

Modules identified by heuristics may also give ideas for product enhancement. Coupling/decoupling module that had been explained before is one of the examples of potential enhancement that can increase the product performance by ensuring that rubber gear and drive couple in blender can be efficiently attached. Another module that can be developed to improve the product performance is the actuating module, where remote control can be added to operate the product. 


\subsection{DISCUSSION}

In this project, three types of products have been taken into consideration. These products were mixer, blender and juice extractor. These are home appliances products from different families and they are chosen due to the simplicity of their function and they are familiar to most of the customers.

The identified modules can initiate product platform from heuristics method and also give some ideas for product improvement. Coupling/decoupling module for example is one module that can be added to product to improve its performance. It can be shown clearly in every variant and platform. Actuating module for mixer, blender and juice extractor are the common on/off switch and speed selector. However, with the use of remote control, user can operate the machine even when they are not in the kitchen.

Waste storing/cleaning module is a value added potential feature in the product. By using this approach, waste can be easily removed without the need to disassemble all the related components which will cause the machine to stop for sometime. This is an inconvenience to the users. Using the modules that have been identified, product performance in the early stages of product design can be improved.

\subsection{CONCLUSION}

Using the method discussed in the paper, modules and platform of products have been successfully identified. The use of modular design and platform architecture provide many benefits to the manufacturer and also to the customer. Product that perform many functions are worth its cost and will attract many customers. From this research, it is concluded that;

(i) Modules from different family product can easily be identified using the method of heuristics rules.

(ii) Sometimes modules that have been identified do not exist in the actual product but the modules can be developed to improve products' performance.

(iii) Similarities between modules identified in product function structure can be used to design product platform.

(iv) Method of module heuristic is an efficient method to identify modules in simple products such as mixer, blender and juice extractor.

(v) Method of module heuristic is an ideal tool for idea generation in improving product performance especially for simple products.

In the future, a prototype of the platform will be fabricated and tested for their functionality and reliability. 


\section{ACKNOWLEDGEMENTS}

The authors would like to acknowledge the School of Mechanical Engineering and Universiti Sains Malaysia for their cooperation and sponsorship in this research work.

\section{REFERENCES}

[1] Huang, C. C. 2000. Overview of Modular Product Development. Proc. National Science Council, ROC (A). 24(3): 149-165.

[2] Pahl, G., and W. Beitz. 1988. Engineering Design. London, U.K.: The Design Council.

[3] Ulrich, K., and K. Tung. 1991. Fundamentals of Product Modularity. Edited by Sharon, A. In: Issues in Design/Manufacture Integration. New York, U.S.A.: ASME. 73-79.

[4] Gonzalez-Zugasti, J., J. Baker, and K. Otto. A Method for Architecting Product Platform with an Application to Interplanetary Mission Design. Research in Engineering Design.12: 61-72.

[5] Huang, C. C., and A. Kusiak. 1998. Modularity in Design of Products and Systems. IEEE Trans. On Sys, Man and Cyber. -Part A: Systems and Humans. 28(1): 66-77.

[6] Brenmer, R. 1999. Cutting Edge Platform. Financial Times: Automotive World. 30-38.

[7] Abdullah, A. B., and Z. M. Ripin. 2002. Module Identification Method: A Qualitative and Quantitative Approach. World Engineering Congress 2002. Sarawak, Malaysia. 38-42.

[8] Martin, M., and K. Ishii. 1997. Design for Variety: Development of Complexity Indices and Design Charts. ASME DETC. CA.

[9] Sudjianto, A., and K. Otto. 2001. Modularization to Support Multiple Brand Platforms. ASME DTM. Pittsburgh PA.

[10] Abdullah, A. B., and Z. M. Ripin. 2003. Modularization to Support Product Platform for Redesign. $19^{\text {th }}$ Int. Conf. on CAD/CAM, Robotics and Factories of the Future 2003. 1: 333-345.

[11] Stone R. B., K. L. Wood, and R. H. Crawford. 2000. A Heuristics Method for Identifying Modules for Products Architectures. Design Studies. 21: 5-31.

[12] Gonzalez-Zugasti, J., and K. Otto. 2000. Modular Platform-based Product Family Design. ASME, Design Automation Conference. Baltimore, MD. 